Pure sodium penicillin sometimes damages the retina slightly when injected intra-vitreously, but its use by this means seems indicated and justifiable in certain cases of infection.

We are very grateful to Dr. W. B. Levinthal for his help in this work and to the W. H. Ross Foundation (Scotland) for the Prevention of Blindness, who defrayed the expenses. The pure penicillin was kindly supplied by Glaxo Laboratories Ltd., the sodium sulṕhacetamide (Albucid soluble) and marfanil by British Schering Ltd., and the V.335 by the Boots Pure Drug Company Ltd.

\title{
BIBLIOGRAPHY
}

Bratton, A. C. and Marshall, E. K. (1939).-Jl. Biol. Chem., Vol. CXXVili, p. 537.

EVANS, D. G., FULLER, A. T. and WALKER. J. (1944).-Lancet (2), p. 523.

Koyanagi, Y. and KINIKAWA, C. (1937).-Arch. of Ophthal., Vol. CXXXVII, p. 261.

LEOPOLD H. I., and SCHEIE, H. B. (1943)-Arch. of Ophthal., Vol. XXIX, p. 811.

Robson, J. M. and ScotT, G. I. (1944).-Brit. Jl. Exper. Path., Vol. XXX, p. 81.

SALLMANN, L., MEYER, K. and GRANDI, J. (1944). - Arch. of Ophthal., Vol. XXXII, p. 179.

\section{A CASE OF THE LAURENCE-MOON-BIEDL SYNDROME SHOWING ATYPICAL RETINITIS PIGMENTOSA ASSOCIATED WITH MACULAR DYSTROPHY *}

\section{BY}

\section{Charles TAYLOR}

LONDON

IN their comprehersive studies on the Laurence-Moon-Biedl syndrome, Cockayne, Krestin and Sorsby (1935), and Sorsby, Avery and Cockayne (1939) have shown that the fundus lesion may be an atypical rather than typical retinitis pigmentosa, and that macular dystrophy with optic atrophy may replace either of these, an observation also made more recently by Lyle (1946). The present case report is of interest in that it shows the combination of atypical retinitis pigmentosa with macular dystrophy. The great rarity of the association of retinitis pigmentosa and macular dystrophy and its hereditary character have been brought out by Sorsby (1940 and 1941).

\section{Case report}

Past History. T. S., aged 24 years, was fat at birth. There was some loss of weight following illness at 3 weeks (said to be "threatened with meningitis"). No attempt was made at talking

\footnotetext{
* Received for publication, January 29, 1947.
} 
until his fifth year when he was sent to school. During his first year at school lenses were prescribed by an ophthalmologist and during his school life he has always occupied the front bench. As far as he can remember there has always been difficulty in getting around after dusk. He rode a bicycle until he was twelve years old, but gave up cycling when he collided with a woman who was crossing the road. In the same year his master forbade him to play cricket. His education was carried on at a private (not "special ") school until he was sixteen years of age when it seemed hopeless to continue. He had a variety of posts which he could not retain and

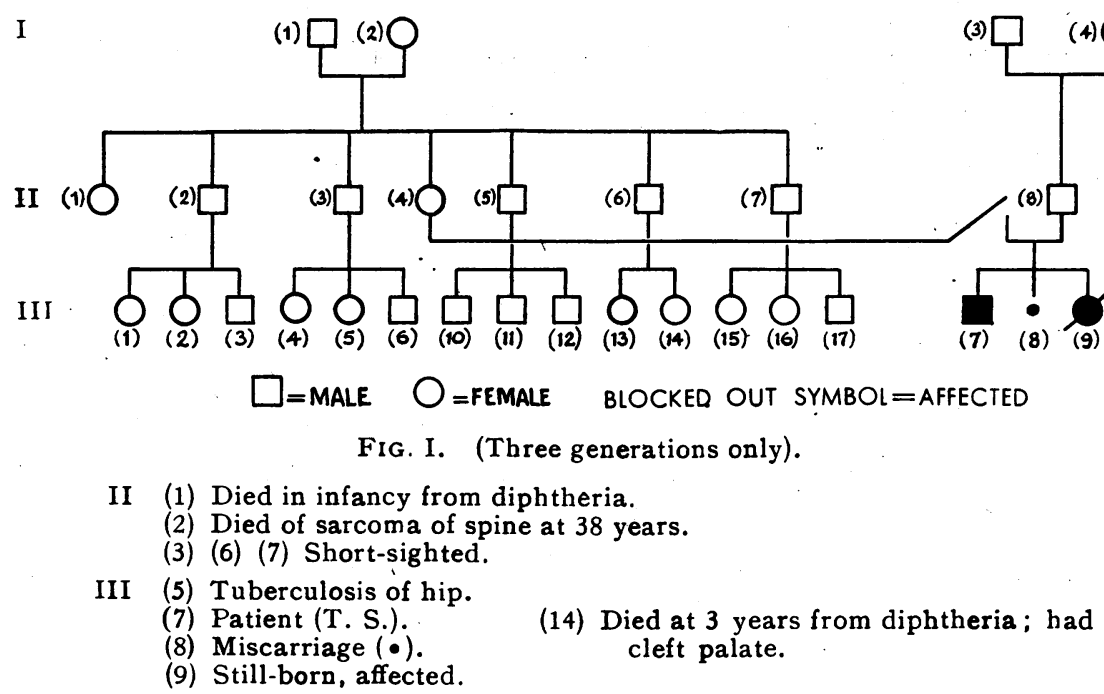

is now employed in a factory, where, by pulling a lever pieces are punched out in a sheet of metal to retain hypodermic needles.

Family history. (Fig. 1). His father and mother are not related. They are both English. The father has always enjoyed good health but the mother has had two nervous breakdowns. The Wassermann reaction in both of them was negative. On the father's side of the family a brother and sister of the great grandmother died in infancy, and a great aunt had several miscarriages and two children who died at one year old, one of which was said to have been born blind.

On the mother's side of the family two children of a great aunt died as babies and one great aunt was very fat.

T. S. was the first born. Twice during pregnancy abortion was threatened. A year later there was a four months' miscarriage, but no details of the foetus are available. The third pregnancy resulted in a stillborn female child with extra fingers and toes and "part of the head missing." 


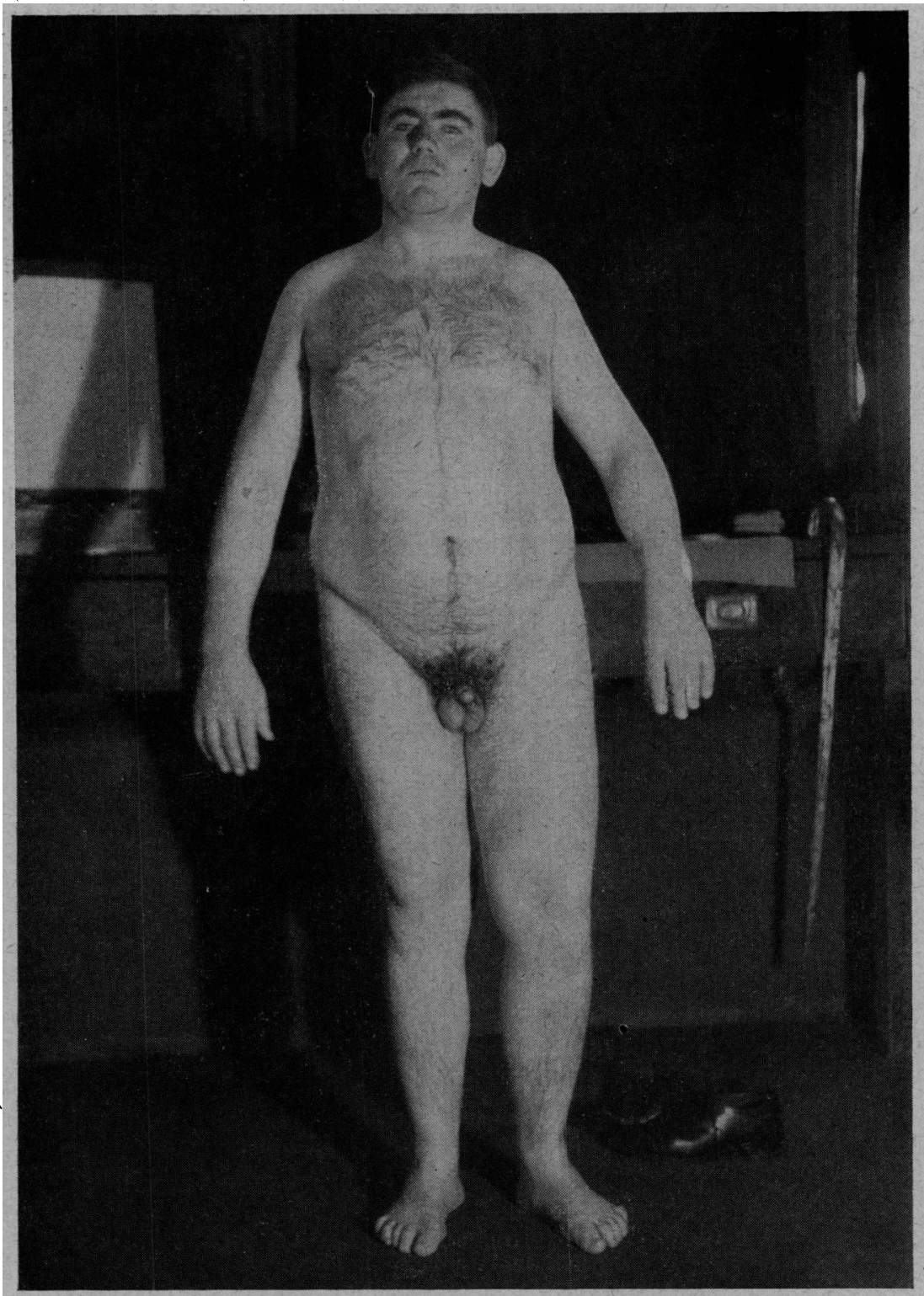

FIG. 2. 
Examination. T. S. is placid and co-operative. Mental retardation is present in only a minor degree and in spite of his visual disability he has a fair knowledge of recent events. He is distinctly obese (Fig. 2). His height is $5 \mathrm{ft} .6 \mathrm{in}$. and his weight $14 \mathrm{st} .2 \mathrm{lb}$. The fat is distributed chiefly on face, chest, abdomen and thighs. His hair is dark. He presents the male distribution of hair on the body and has to shave every day. The testicles are descended and within normal limits of size. The penis is undersized and the voice high-pitched.

Scars are present on the ulnar side of the right hand over the head of the fifth metacarpal and on the outer side of each foot over the heads of the fifth metatarsals. The extra digits were removed in childhood. Dorsal scoliosis and genu valgum are present.

Vision of each eye with correction:-

$$
\text { (R. } \frac{-1.50 \text { D. sph. }}{-2 \cdot 0 \text { D. cyl. } 60^{\circ}} \text { L. } \frac{-1 \cdot 0 \text { D. sph. }}{-2 \cdot 0 \text { D. cyl. } 180^{\circ}} \text { ) }
$$

and without correction is $2 / 60$ after much searching. There is complete and absolute loss of the peripheral fields and as far as can be ascertained only small receptive areas in the perimacular regions remain. The left eye is divergent 5-10 degrees. Both pupils are equal and react to light and convergence accommodation. Constant

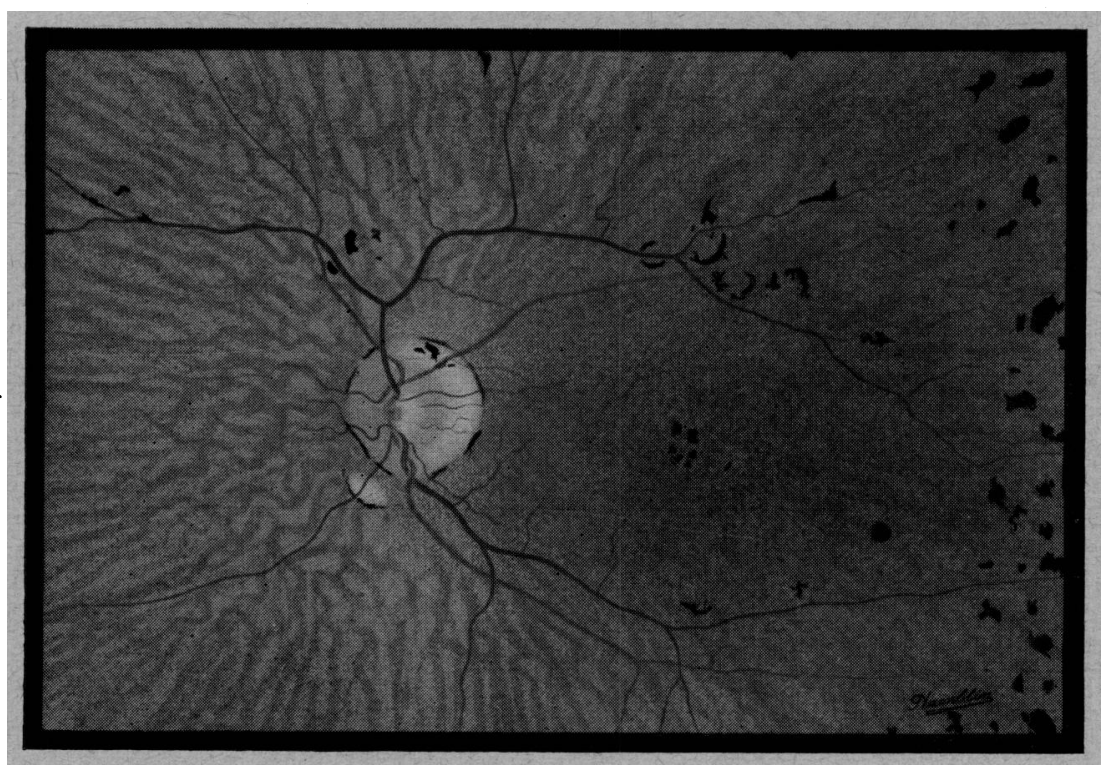

FIG. 3.

Left fundus of $T$. S. 
bilateral nystagmus of the pendulum type is present. It is slow in rate, and increased in range on lateral fixation. A small posterior polar cataract is present in each eye. The fundi (Fig. 3) are lacklustre. Small patches of pigment of varying shapes are scattered over the fundi but "bone corpuscle". pigmentation is not predominant. In addition there is a fine peppering of pigment where the tapeto-retinal atrophy is more marked. Occasional small circumscribed areas of retino-choroidal atrophy are present. The maculae are spotted with pigment. The retinal vessels are diminished in calibre. Unmasking of the choroidal vessels is present over the greater part of both fundi except in the macular and perimacular regions.

Motor and sensory functions of the cranial nerves (apart from 2nd nerves) are normal.

Muscle tone and power in the limbs is good. There is no ataxia. Deep and superficial reflexes are normal and sensation good.

Examination of heart, lungs, and abdomen reveals no abnormality.

Blood pressure: Systolic 128. Diastolic 87. Urine: No abnormality. No polyuria or polydipsia. Blood: Wassermann reaction : negative. X-ray of skull shows nornal conformation. The sella turcica shows no abnormality. X-ray of hands and feet: nil abnormal.

\section{Remarks}

Reviews of the collected families present a large number of miscarriages and early deaths indicating that the expression of the genes may be so severe as to result in non-viability or early death. In this sibship it may be that the miscarriage was due to this cause and there is little doubt that this accounts for the still birth of the affected female child.

The present case taken in connection with the previously reported cases, indicates that the range of fundus lesions in the LaurenceMoon-Biedl syndrome extends to at least four variants of tapetoretinal degeneration: typical retinitis pigmentosa, atypical retinitis pigmentosa, macular dystrophy, and atypical retinitis pigmentosa combined with macular dystrophy.

I am indebted to Mr. L. H. Savin for the opportunity to report the case, and to Professor Arnold Sorsby for his kind assistance.

\section{REFERENCES}

Cockayne, E A., Krestin, D. and Sorsby, A. (1935).-Quart. Jl. Med,. Vol. IV, p. 93.

LYLE, D. J. (1946).-Amer. Jl. Ophthal., Vol. XXIX, p. 939.

SorsBY, A. (1940).-Brit. Jl. Ophthal., Vol. XXIV, p. 469.

-(1941).-ibid, Vol. XXV, p, 524.

Sorsby, A., Avery, H. and Cockayne, E. A. (1939).-Quart. Jl. Med., Vol. VIII, p. 51 . 